\title{
Vulnerability of ecosystems with Guadua angustifolia in Ecuador in light of climate changes ${ }^{1}$
}

\author{
Mario José Añazco Romero²
}

\section{ABSTRACT}

Guadua angustifolia bamboo is historically used by an important percentage of the rural and peri-urban population of Ecuador, especially in the construction of bridges, when events like El Niño and its consequential flooding occur. This study aimed to determine, in light of some climate change scenarios, the vulnerability rate of ecosystems where the G. angustifolia bamboo species occurs, in the coastal region of continental Ecuador. The analysis methodology, with focus on the sampled units, was based on vulnerability assessment tools for climate adaptation recommended by the Intergovernmental Panel on Climate Change. Temperature presented the highest correlation coefficient with the vulnerability rate of the ecosystems, followed by the increase in the sea level, winds and landslides. It was concluded that as the exposure and sensitivity variables increase, the adaptive capacity of ecosystems with occurence of this species decreases, and isolated plants and monoculture plantations are the most vulnerable to climate changes.

KEYWORDS: Bamboo, climate, vulnerability rate.

\section{INTRODUCTION}

Climate change has caused impacts on natural and human systems on all continents and oceans (IPCC 2014). Agricultural sectors - crops, livestock, fish, aquaculture and forest activity - possess unique characteristics that place them in the center of world forces geared towards the adaptation to these changes (FAO 2016).

Forests are essential as much for the mitigation of climate change as for adaptation (FAO 2018a, 2010). As proof, in recent decades, the services of regulation supply for forest ecosystems have claimed more and more importance, especially the duties of forests and trees in light of climate change, i.e., carbon sequestration and climate regulation (FAO et al. 2018b).

\section{RESUMO}

Vulnerabilidade de ecossistemas com Guadua angustifolia no Equador frente a cenários de mudanças climáticas

O bambu Guadua angustifolia é historicamente utilizado por porcentagem significativa da população rural e periurbana do Equador, em especial na construção de pontes, quando ocorrem inundações resultantes de fenômenos como o El Niño. Objetivouse determinar, em face de alguns cenários de mudanças climáticas, o índice de vulnerabilidade de ecossistemas onde ocorre a espécie G. angustifolia, na região costeira do Equador continental. A metodologia de análise, com foco nas unidades amostradas, baseouse em ferramentas de avaliação da vulnerabilidade para adaptação ao clima recomendadas pelo Painel Intergovernamental de Mudanças Climáticas. A temperatura apresentou o maior coeficiente de correlação com o índice de vulnerabilidade dos ecossistemas, seguida pela elevação do nível do mar, ventos e deslizamentos de terra. Concluiu-se que, à medida que as variáveis exposição e sensibilidade aumentam, diminui-se a capacidade de adaptação de ecossistemas com ocorrência dessa espécie, e plantas isoladas e plantações em monocultivo são os mais vulneráveis a mudanças climáticas.

PALAVRAS-CHAVE: Bambu, clima, índice de vulnerabilidade.

Bamboo, due to its ability to produce abundant biomass in a short time, adjusts atmospheric carbon (Yiping et al. 2010), protects the soil and waterways, and is recognized as an adequate plant to confront climate change (Shawkat et al. 2015). The primary suggestion is to use species like woody bamboos within forest and/or agroforestry systems (Arun et al. 2015).

Ecuador is a country catalogued as vulnerable to climate change (Ludeña \& Wilk 2013) and the National Strategy for Climate Change of Ecuador (ENCC) contemplates developing actions to mitigate this vulnerability (MAE 2017). The action lines of the ENCC are subdivided into seven sectors, two of which are logging and agriculture (Ecuador 2012). Within these, bamboo is part of natural ecosystems 
and agroforestry settlements, interacting with agricultural and pasture species.

Historically, in Ecuador, the Guadua angustifolia Kunth bamboo, known as caña guadua, has shown a significant social contribution for rural and urban inhabitants living on the coastal area. There is a long-standing tradition to construct elevated homes from bamboo to avoid floods. G. angustifolia is preferred in the construction of homes due to its seism-resistant properties. About $9 \%$ of the homes in Ecuador (331,579 housing units) use caña guadua as a predominant material in the walls (INEC 2015).

In Ecuador, native and introduced bamboo species may be found distributed in the four natural regions of the country (coast, mountains, Amazon and Galapagos), from the sea level to close to $4,300 \mathrm{~m}$ (a.s.1.), where the Neurolepis genus inhabits. Six genera and 44 species of native bamboo have been identified, of which 11 are endemic: Arthrostylidum with three species; Aulonemia with five species; Chusquea with 18 species; Guadua with five species; Neurolepis with 11 species; Phipidocladum with one species; and Rhipidocladum with one species (Londoño 2011).

The first exotic species introduced in 1923 were Phyllostachys aurea and Phyllostachys bambusoides. Currently, Bambusa vulgaris, Bambusa tulda, Bambusa ventricosa, Dendrocalamus asper, Dendrocalamus latiflorus, Dendrocalamus longispiculata, Dendrocalamus oldhamii (syn. Bambusa oldhamii), Melocanna baccifera, Phyllostachys nigra and Phyllostachys pubescens can also be found. The surface area with bamboo in Ecuador is 600,026 ha (Ecuador 2018), of which $34 \%$ correspond to G. angustifolia, $16 \%$ to D. asper, and the remaining $50 \%$ include various species that belong to the genera Chusquea, Neurolepis and Gynerium (Añazco \& Rojas 2015). In their natural and planted states, $60 \%$ are natural patches predominantly with $G$. angustifolia, and the other $40 \%$ correspond to plantations where G. angustifolia and $D$. asper are more frequent and, in smaller proportions, $P$. aurea and $B$. vulgaris.

$G$. angustifolia is endemic of America and native from Colombia, Venezuela and Ecuador (Londoño 2011). It can grow up to $30 \mathrm{~m}$ in height and $0.22 \mathrm{~m}$ in diameter. It is considered the third largest bamboo in the world, surpassed by only two Asian species: Dendrocalamus giganteus and Dendrocalamus sinicus (Corpei 2005). There are two varieties: G. angustifolia var. bicolor and G. angustifolia var. nigra. The "bicolor" variety manifests as a green culm with yellow streaks, and the "nigra" has a green culm with light black spots. Locally, they are distinguished by different names as caña brava (wild cane), caña mansa (gentle cane), cebolla (onion), macana (baton), cotuda (fluffy) or castilla (castile).

It is recognized as one of the twenty best species of bamboos in the world that, due to its ability to absorb energy and tolerate a greater flexion, has been converted into an ideal material for seismresistant constructions. Morán (2001) mentions that there are more than 1,000 uses attributed to this species, which have been recorded from before pre-Columbian times. According to the level of transformation, three categories for the use of caña guadua are distinguished in Ecuador: i) primary products; ii) semi-workable products or primary transformation products; iii) greater added value (Añazco \& Rojas 2015).

Currently, the important contributions of bamboo to the local and national economies are seen as very important. It is estimated that Ecuador consumes 20,903,800 stalks of bamboo annually, of which $15,531,400$ correspond to $G$. angustifolia. It is calculated that 600,000 people are directly involved in the bamboo chain in the country, what represents about $4 \%$ of the total population. These participants move about \$90,000,000 USD annually (Añazco \& Rojas 2015).

In the near future, bamboo is envisaged to have substantial contributions for the environment, particularly with climate change. In mitigation, it contributes to the fixation and storage of carbon in its biomass. In Colombia, Camargo et al. (2010) determined that, at a seven-year-old plantation, G. angustifolia had a fixation of $76.6 \mathrm{t} \mathrm{C} \mathrm{ha-1}$, of which $83 \%$ are accommodated in the air biomass. In the vulnerability framework for climate change, bamboo fulfills various roles and functions, among them protection from landslides (FAO 2009), defense of riverbanks, and it also acts on the microclimate.

The presence of bamboo at riverbanks creates a natural contention wall that detains sediments, rocks, trees and other elements that are pulled along by water currents (Umaña 2009). This is largely due to the interwoven system of rhizomes and rootlets that behave as efficient biological retaining walls. Thus, G. angustifolia represents a species with a 
protective special function to be used in hillside soils of hydrographic basins (Herrera 2010). Morán (2005) still reports its use to protect and stabilize slopes and landslides, what ensures a soil recovery and erosion control.

At the microclimate level, locally, the "thermostatic" effect of bamboo plantations is also very appreciated. This phenomenon is produced when the plant transpires, losing water in the air in the form of vapor, generating a thermic sensation within the stand of trees that is lower than outside it (Primavesi 1984).

Despite this great potential, there is an increasing need for scientific information about the role that bamboo plays in light of climate changes in general and, in particular, on the vulnerability of the ecosystems in which such plant occurs. With this purpose, this study aimed to determine the vulnerability rate of some ecosystems where G. angustifolia is present in the coastal region of continental Ecuador.

\section{MATERIAL AND METHODS}

This investigation is part of more general studies sponsored by the International Network for Bamboo and Rattan (INBAR), in Ecuador, carried out between 2011 and 2015. The study was completed on the Ecuador coast, defined as "the region situated between the Pacific Ocean and the foothills of the Andes mountain range" (MAE 2013). The provinces selected were Manabi, Pichincha, Guayas and El Oro (Figure 1). In each province, the main watersheds and respective sub-basins were chosen where bamboo has the highest presence, namely: Portoviejo River in Manabi, Caoni River in Pichincha, Chimbo River in Guayas, Muyuyaco River in El Oro and Siete River, located between the provinces of Guayas and El Oro.

The hydrographic sub-basins of the Chimbo and Caoni rivers are representatives of the Tropical Rainforest vegetal formation, located between $100 \mathrm{~m}$ and $300 \mathrm{~m}$ (a.s.1.), with an average annual temperature of $25^{\circ} \mathrm{C}$ and average rainfall of 2,383$2,743 \mathrm{~mm}$ per year. The sub-basins of the Portoviejo, Muyuyaco and Siete rivers are located between $6 \mathrm{~m}$ and $100 \mathrm{~m}$ (a.s.1.), with an average annual temperature of 21-31 ${ }^{\circ} \mathrm{C}$ and average rainfall of 400-1,000 mm per year; which represent the tropical dry forest.

Based on the climate change scenarios, in the province of Manabi, an increase in the "Indian

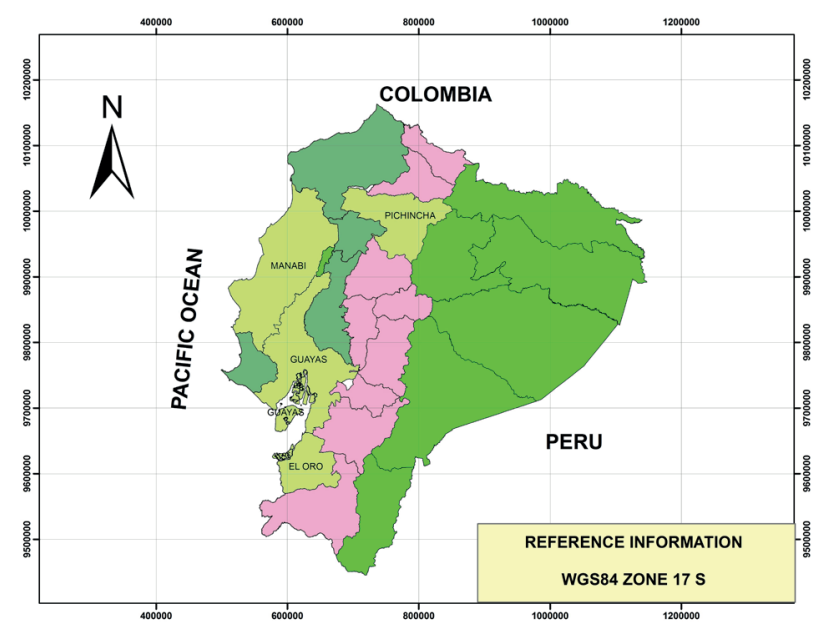

Figure 1. Map of Ecuador with its regions, provinces and study areas of bamboo.

Summer" (consecutive dry days) and in the rainfall intensity are noted. If the current patterns of vulnerability are maintained, the province will end up affected, from an agricultural and forestry point of view. In the northwest of the Pichincha province, the risk maps show a trend to increased heavy rains in short periods, mainly in some agricultural areas. According to the scale adopted, the existence of a high risk can be observed in the zone near the Caoni River (CIIFEN 2007).

The province of Guayas shows a high vulnerability in the zone of the Chimbo river, from where the Yaguachi and Chilintomo rivers are defined, supporting highly significant agricultural activities (CIIFEN 2012). In the province of El Oro, increases of $5-15 \%$ in the annual rainfall and $1.0-1.2{ }^{\circ} \mathrm{C}$ in the average annual temperature are expected in the next twenty years (CIIFEN 2016).

The criteria used to define the study units were: i) sub-basins representative of the biophysical conditions where bamboo is developed; ii) production systems with natural stands, forestry plantations, agroforestry systems and isolated plants; iii) structure of bamboo actors with small, medium and large producers or owners. The features of the units chosen to take the field information are described as it follows:

- Portoviejo River: natural stands and isolated plants on private land of small farmers (smaller than 1.0 ha to 2.0 ha);

- Caoni River: silvopastoral systems (G. angustifolia + Brachiaria spp.) and natural stand belonging to mid-sized property owners (2.0-10 ha), 
and bamboo plantations of large-sized property owners (greater than $10 \mathrm{ha}$ );

- Chimbo River: silvopastoral systems (G. angustifolia + Brachiaria spp.) and plantations belonging to large-property owners and natural stands on land of mid-sized property owners;

- Muyuyaco River: agroforestry system (G. angustifolia + Theobroma cacao) and isolated plants on the land of small-sized property owners;

- Siete River: plantation of 100 ha of $G$. angustifolia and isolated plants on land of midsized property owners.

In total, 12 units were selected for the study, of which $25 \%$ correspond to natural stands with small and mid-sized producers; $25 \%$ to plantations of large-sized producers; $25 \%$ to agroforestry systems with small, medium and large-sized producers; and $25 \%$ to isolated plants with small and mid-sized producers.

The analysis of vulnerability to climate change was completed based on the definitions indicated in the conceptual framework proposed by Lim \& Spanger-Siegfried (2006). Vulnerability was related to social units, and biophysical systems were described as risk-sensitive variables or climate stress. In this approach, vulnerability (V) is analyzed as a function of three main variables: $V=f(E, S, C A)$; where: $\mathrm{E}$ is the exposure, $\mathrm{S}$ the sensitivity and $\mathrm{CA}$ the adaptive capacity.

For these three explanatory variables, 27 indicators were defined: 12 to characterize exposure, 6 for sensitivity and 9 for adaptive capacity. In each variable, a sub-rate was calculated, which was used as inputs to determine the general vulnerability rate of the G. angustifolia species.

In the exposure variable, five of the analyzed indicators were directed towards examining what is at risk due to climate change, and the other seven to assess the changes that the bamboo system will come across: population that depends on bamboo (affected population and its uses); ecology (soil, biodiversity, pests and diseases); property and surface; infrastructure for the bamboo management, use and transformation; age of the bamboo subsystems; sea level; temperature; pluvial precipitation; landslides; winds; fires; and extreme events.

For the sensitivity variable, the biophysical effects of climate change were studied, keeping in mind the socioeconomic context. The analyzed indicators were the following ones: perceptions about the "bamboo:ecosystemic services" relationship, in the case of water; bamboo industry; human settlements; energy demand; forests and their relationship with bamboo and financial services.

The adaptive capacity was the variable that allowed the analysis of how a system can adjust to climate change, climate variability and extreme episodes. The indicators subjected to analysis were the following ones: history; social context; culture; economy; technology; norms; legal and institutional support; and information.

To calculate the general vulnerability index, first, vulnerability sub-rates were obtained for each indicator. For this, an adaptation of the procedure used for calculating the indices of environmental services by the US Conservation Reserve Program was used, as well as others such as the one used in Nicaragua for the same objectives (Pagiola et al. 2007). A partial calculation scale of values was defined with the following ranges: high vulnerability (0.0-0.45); medium vulnerability (0.45-0.75); and low vulnerability $(0.75-1.0)$. Once the sub-rates were obtained, vulnerability rates were calculated for each variable and, finally, the general vulnerability rate was calculated by the following formula: vulnerability = exposure + sensitivity - adaptive capacity.

The methodological route was composed by nine processes: i) secondary information (books, reports, articles and internet sites); ii) electronic survey; iii) workshop with Guadua experts; iv) workshop with partners of the INBAR; v) perceptions shared by farmers (sample size, $\mathrm{n}=28)$; vi) field visits $(\mathrm{n}=11)$ : ecosystems and people involved with the bamboo value chain; vii) visits to processing centers, marketing and bamboo uses $(n=17)$; viii) consultations with experts $(\mathrm{n}=16)$; ix) bamboo inventory. The indicators for the methodological tools used are shown in Table 1.

Pearson's correlation coefficients were determined between the vulnerability rate and the 27 analyzed indicators, as well as with the partial rates of vulnerability associated to the variables exposure, sensitivity and adaptive capacity (a total of thirty analyzes). Linear regression analyses were also adjusted to determine the correspondence between the behavior of the bamboo ecosystems and the different aspects of vulnerability. In addition, a cluster analysis of the variables was performed to determine the similarities between the studied ecosystems. 
Table 1. Methodological tools, indicators and main explanatory variables used for the analysis of vulnerability of Guadua angustifolia in the coastal region of continental Ecuador.

\begin{tabular}{|c|c|c|}
\hline Methodological tools & Indicator & Variable $^{1}$ \\
\hline \multirow{3}{*}{ Guadual inventory (INBAR 2010) } & 01. Ecology & $\mathrm{E}$ \\
\hline & 02. Age & $\mathrm{E}$ \\
\hline & 03. Forest and its relationship with bamboo & $\mathrm{S}$ \\
\hline Case study (Zea 2013) & 04. Perceptions vs. scientific evidence & $\mathrm{S}$ \\
\hline \multirow{7}{*}{ Focal group } & 05. Population that depends on bamboo & $\mathrm{E}$ \\
\hline & 06. Property and surface & $\mathrm{E}$ \\
\hline & 07. Human settlements & $\mathrm{S}$ \\
\hline & 08. History & $\mathrm{AC}$ \\
\hline & 09. Social & $\mathrm{AC}$ \\
\hline & 10. Cultural & $\mathrm{AC}$ \\
\hline & 11. Fires & $\mathrm{E}$ \\
\hline \multirow{5}{*}{ Cost/benefit } & 12. Economy & $\mathrm{AC}$ \\
\hline & 13. Infrastructure & $\mathrm{E}$ \\
\hline & 14. Financial services & $\mathrm{S}$ \\
\hline & 15. Energy demand & $\mathrm{S}$ \\
\hline & 16. Institutional & $\mathrm{AC}$ \\
\hline \multirow{11}{*}{ Delphi method (Pozo et al. 2007) } & 17. Information & $\mathrm{AC}$ \\
\hline & 18. Industry & $\mathrm{S}$ \\
\hline & 19. Legal & $\mathrm{AC}$ \\
\hline & 20. Politics & $\mathrm{AC}$ \\
\hline & 21. Technology & $\mathrm{AC}$ \\
\hline & 22. Sea level & $\mathrm{E}$ \\
\hline & 23. Temperature & $\mathrm{E}$ \\
\hline & 24. Pluvial precipitation & $\mathrm{E}$ \\
\hline & 25. Landslides & $\mathrm{E}$ \\
\hline & 26. Winds & $\mathrm{E}$ \\
\hline & 27. Extreme events & $\mathrm{E}$ \\
\hline
\end{tabular}

${ }^{1}$ E: exposure; S: sensibility; AC: adaptive capacity.

\section{RESULTS AND DISCUSSION}

Based on a nested structure, the results were presented in system and subsystem levels, as well as internal vulnerability rate for each indicator (Figure 2). The bamboo ecosystem represented by the G. angustifolia native species presents a vulnerability rate of 0.56 , classified as medium. This rate contrasts what occurred in the biophysical and socioeconomic contexts where the species is developed. In the closest environment, which are the micro-basins and provinces of the Equatorial coast, these present high vulnerability rates. This also happens at a national level, being catalogued at high vulnerability (CAF 2014).

From this situation, it may be deduced that G. angustifolia can be used as part of the design of norms and/or strategies to confront climate changes in Ecuador. Arun et al. (2015) deliberated the role in the adaptation and mitigation of climate change of bamboo, to which they add the notable contribution to the social, economic and environmental aspects of rural life. Arce (2013) indicates that there is a greater vulnerability in the field of rural settings of Latin America and proposes different strategies for institutional and community competence.

The G. angustifolia bamboo system in Ecuador is made up of four subsystems: natural stands, plantations, agroforestry systems and isolated plants. Regarding the vulnerability rate, these show a difference in their behavior, where dispersed plants stand out as those that show the lowest rate and, therefore, they are the most vulnerable to climate change, while natural stands are the most resistant to this phenomenon (Figure 2). Here is also illustrated that the high vulnerability situation of dispersed plants complies with their degree of exposure, which depends on natural and anthropogenic factors, being the main ones extreme events, winds and landslides, while the secondary ones are fires.

Furthermore, at the internal level of each sub-system, its structure is a determinant factor, 


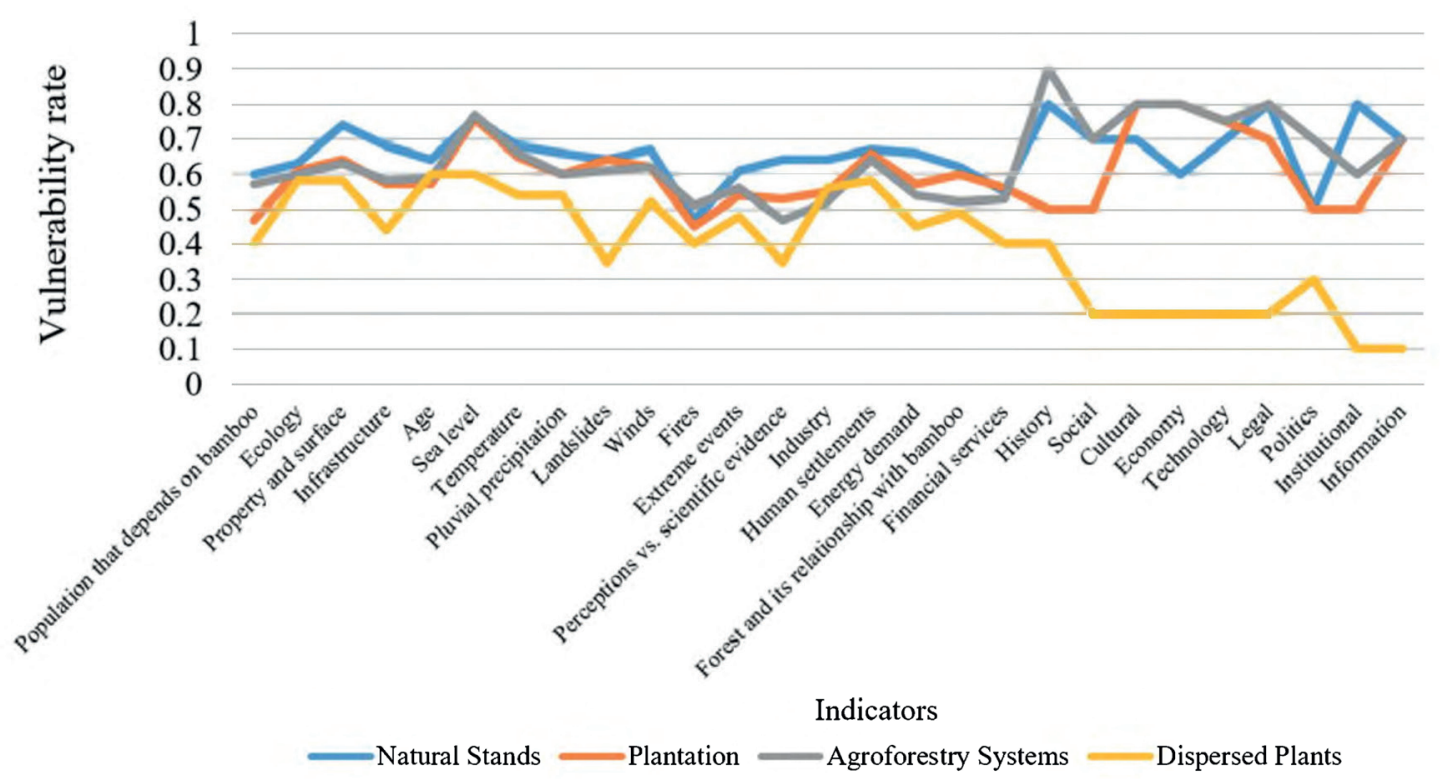

Figure 2. Vulnerability rates associated with 27 indicators for four bamboo subsystems in the coastal region of continental Ecuador.

as the complex structure that natural stands and agroforestry ecosystems possess generates a greater resistance against monocultures or isolated plants. Muñoz-Lopez et al. (2017) point out the following categorization of eco-systemic services provided for Guadua forests: regulation of environmental disturbances, security against disasters and regulation of the water cycle.

Statistically, dispersed plants end up being different from the rest of the subsystems. Agroforestry and plantation systems are the ones that show most similarities, above all in respect to exposure (Figure 3). The vulnerability level of these ecosystems may serve as a reference to define adaptive management technologies in light of the impacts of climate change (Felicisimo 2011).

The level of significance, in accordance to the vulnerability rate, resulted differently with each variable. Sensitivity was significant, and both the exposure and adaptive capacity resulted in highly significant (Table 2).

For the regression analysis, determination coefficients were greater than $70 \%$ on the exposure and sensitivity variables, among the plantation subsystem, natural stands and agroforestry systems. It should be noted that the greatest adjustment to
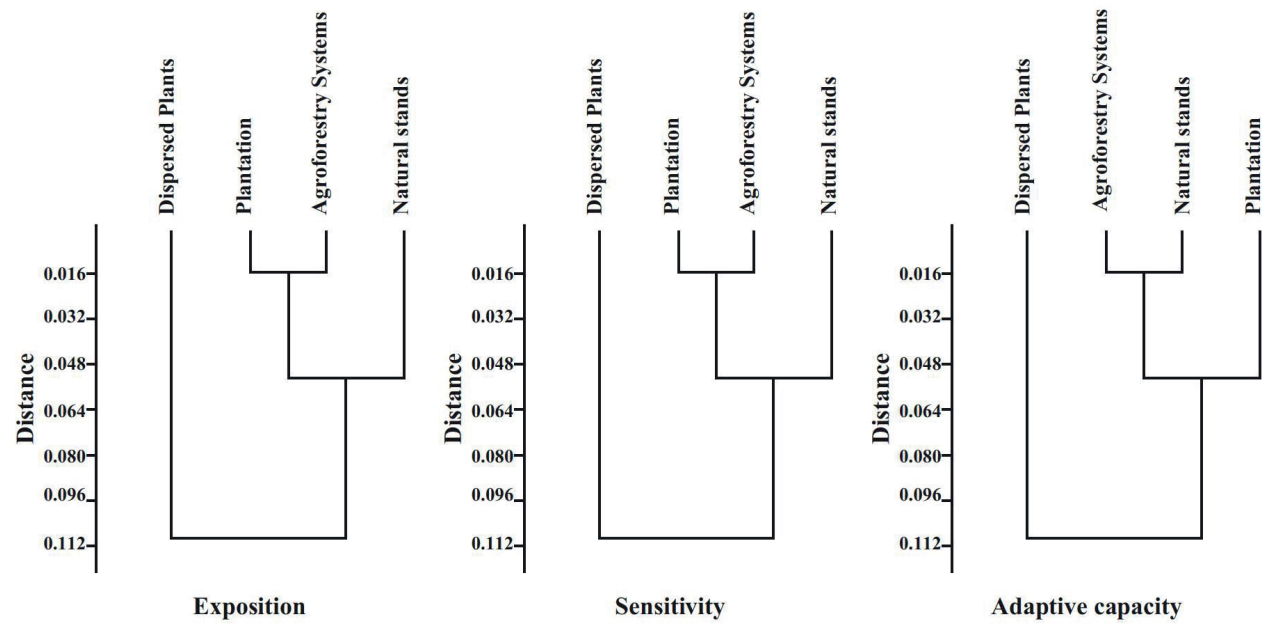

Figure 3. Cluster analysis of the vulnerability variables for bamboo ecosystems with Guadua angustifolia in the coastal region of Ecuador. 
Table 2. Correlation coefficients between the vulnerability rate and the main explanatory variables and indicators for bamboo ecosystems with Guadua angustifolia in the coastal region of Ecuador.

\begin{tabular}{|c|c|c|}
\hline Variables & Indicators & Correlation \\
\hline \multirow{2}{*}{ Exposure: what is at risk } & Population depends on the reeds & 0.899* \\
\hline & Infrastructure & $0.942 *$ \\
\hline \multirow{6}{*}{ Exposure: changes in the system } & Increase in the sea level & $0.976^{* *}$ \\
\hline & Temperature & $0.999 * *$ \\
\hline & Precipitation & $0.906^{*}$ \\
\hline & Winds & $0.976 * *$ \\
\hline & Landslides & $0.974 * *$ \\
\hline & Extreme events & $0.931 *$ \\
\hline \multirow{3}{*}{ Sensitivity } & Human settlements & $0.953^{*}$ \\
\hline & Energy demand & $0.883^{*}$ \\
\hline & Financial services & $0.954 *$ \\
\hline \multirow{6}{*}{ Adaptive capacity } & Social & $0.967 * *$ \\
\hline & Cultural & $0.934 *$ \\
\hline & Technological & $0.991 * *$ \\
\hline & Legal & $0.994 * *$ \\
\hline & Institutional & $0.974 * *$ \\
\hline & Information & $0.978 * *$ \\
\hline What is at risk & - & $0.883 * *$ \\
\hline Changes in the system & - & $0.999 * *$ \\
\hline Exposure & - & $0.975 * *$ \\
\hline Sensitivity & - & $0.873 * *$ \\
\hline Adaptive capacity & - & $0.984 * *$ \\
\hline
\end{tabular}

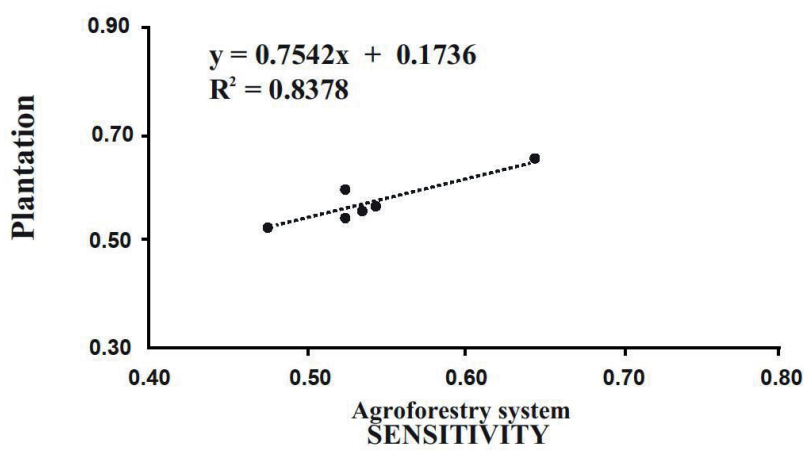

the regression line was presented in the indicators of exposure between plantation and agroforestry system (Figure 4).

In the present study, all correlations with winds and landslides standing out were high, since such variables may, in fact, cause important changes on the bamboo system (Table 2). This coincides with the fact that, in Colombia, G. angustifolia is planted to prevent landslides (Yiping \& Henley 2010, Turbay et
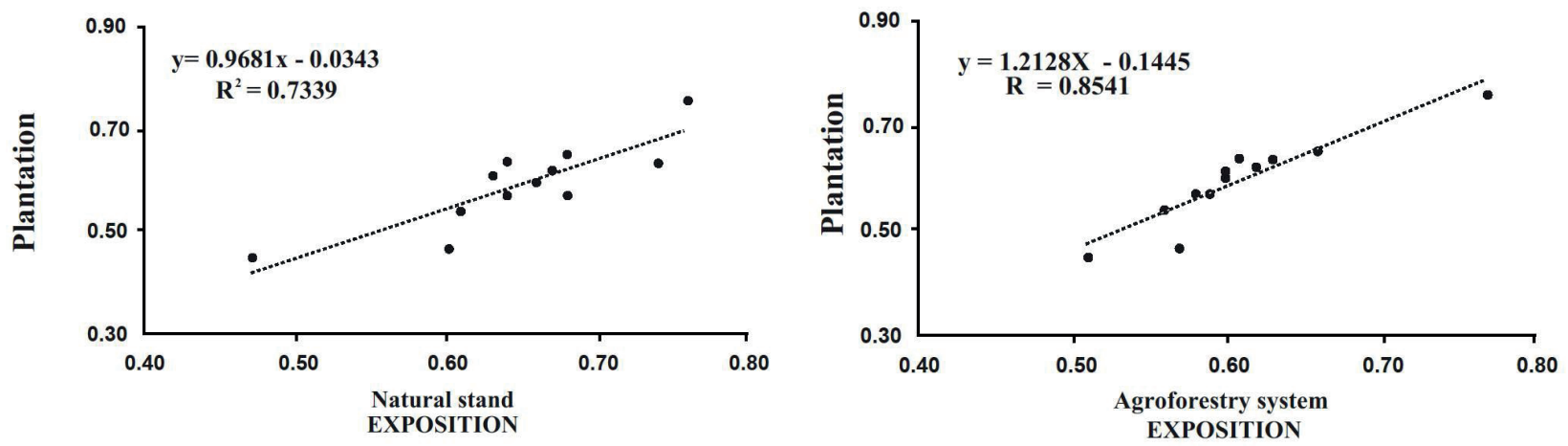

Figure 4. Diagrams of dispersion and regression lines between vulnerability variables and ecosystems with bamboo. 
al. 2014), and it is also consistent with a study about the vulnerability of $G$. angustifolia used in housing to climate change that was completed in the north of Peru (Barnet el al. 2014).

The groups of indicators with the highest correlations shown in the characterization of the vulnerability were: temperature, winds, increase in the sea level and landslides for exposure; financial services for sensitivity; and legal and technological indicators for adaptive capacity (Table 2). On the other hand, those with the smallest correlations were: population for exposure; energy demand for sensitivity; and cultural indicator for adaptive capacity. The former is similar to the indicators that best correlated in the characterization of vulnerability and climate change in the agriculture of Mexico (Monterroso et al. 2012).

In the case of the agriculture of Ecuador and, in particular, the rural, family agriculture by which cacao is managed (associated with $G$. angustifolia in some manners), the scenarios show a positive impact of up to $+11 \%$ at the level of economic income for the decades 2020 and 2030 (Jiménez et al. 2012). This situation corresponds to the results of the present study, where the agroforestry systems present low vulnerability rates (Figure 2 ).

A total of 17 of the 27 indicators are directly related with the vulnerability rate (Table 2). Their correlation coefficients present significance at $5 \%$ or $1 \%$ of probability. The greatest correlation coefficient between the vulnerability rate and the indicators was with the temperature (0.99). This situation is cohesive with world and national projections, in respect to the scenarios of climate change that indicate increase in temperature, like that indicated by the third national communication of $0.6{ }^{\circ} \mathrm{C}$ for the Ecuador coast (MAE 2017). At the national level, climate models predict a substantial warming of $5-6{ }^{\circ} \mathrm{C}$ by the end of the century (Vanacker et al. 2018).

Studies about the impact of climate change scenarios on the biodiversity in Ecuador indicate that "the patterns of richness of species have an ascending slope, generating a loss of species for many of the studied groups, particularly angiosperms" (Cuesta et al. 2015). This slope implies mainly in changes in the temperature and rainfall patterns. This scenario will probably not affect the bamboo ecosystems with G. angustifolia, that has an optimal development between $17{ }^{\circ} \mathrm{C}$ and $26{ }^{\circ} \mathrm{C}$, with the stretching that may occur under $11^{\circ} \mathrm{C}$ and $36^{\circ} \mathrm{C}$. The species grows sparsely in areas where the pluvial precipitation is less than 1,200 $\mathrm{mm}$ per year. The best stands are present where the rainfall range is between $2,000 \mathrm{~mm}$ and 2,500 $\mathrm{mm}$ per year.

Winds and landslides are basic indicators to consider in vulnerability, due to the fact that $35 \%$ of the Ecuadorian population live in zones threatened by landslides, floods, mudflows and debris. In addition, $30 \%$ of the populations in the coastal and Amazon regions and $15 \%$ of the natural surface are subject to periodic flooding (MAE 2011). Winds between June and August are of higher frequencies and associated with forest fires, since this is the period of least rainfall. Fires resulted being the indicator that registered the greatest vulnerability rate in this study.

Referring to extreme events, they have characterized the Ecuador's climate during the last years, causing significant social, environmental and economic impacts (MAE 2015). When these events occur, such as the El Niño phenomenon, bamboo ecosystems are more required, as G. angustifolia stalks are used for the construction of bridges, housing and agricultural infrastructure.

The pluvial precipitation presents a high significance, and its correlation level is less than for temperature (Table 2). The precipitation on the coastal region may increase by $33 \%$ in the coming years (MAE 2017), but this would not affect the bamboo ecosystems, because the $G$. angustifolia species has a wide range of rainfall adaptation levels (between 1,200 $\mathrm{mm}$ and 3,000 $\mathrm{mm}$ per year).

Although there is no scientific evidence of the precise water requirements to maintain bamboo plantations, especially when they have commercial objectives, it is important to know that bamboo does not tolerate prolonged periods of drought. Bowyer et al. (2014) state that monopodial bamboo develops better in environments with warm and humid climates, with rainfall levels greater than $1,200 \mathrm{~mm}$ per year. This is important, because, according to the study "Climate Information of Hydrometeorological Threats in the Coastal Provinces of Ecuador" (MAE 2011), there are areas prone to both scarcity and excess of rainfall, one of those being the province of Manabi, where there are important zones with the presence of $G$. angustifolia.

The social, legal, institutional, technological and informational aspects showed high levels of significance (Table 2). In addition, culture, population, infrastructure, energy demand, human settlements 
and financial services also showed significance. The Ministry of Environment of Ecuador defines these indicators as "non-climatic factors that make people more or less vulnerable, and, therefore, acting on these factors will promote a more resilient Ecuadorian society" (MAE 2017).

Among the legal instruments, the National Strategy for Climate Change is highlighted (Ecuador 2012), which aims to reduce the social, economic and environmental vulnerability against the impacts of climate change. The studied bamboo ecosystems would form an intrinsic part of this public policy.

\section{CONCLUSION}

As exposure and sensitivity increase, the adaptive capacity decreases for each sub-system of Guadua angustifolia, a situation reflected in the vulnerability rate of isolated plants and monoculture plantations, that ends up being the most vulnerable to climate change.

\section{ACKNOWLEDGMENTS}

To the International Network for Bamboo and Rattan (INBAR - Ecuador), for supporting this research from the beginning; and the National Work Group About Volunteer Forestry Certification in Ecuador (CEFOVEFSC), for its collaboration at the final edition of this article.

\section{REFERENCES}

AÑAZCO, M.; ROJAS, S. Estudio de la cadena desde la producción al consumo del bambú en Ecuador con énfasis en la especie Guadua angustifolia. Quito: INBAR, 2015.

ARCE, R. Ordenamiento territorial y cambio climático: metodología para incorporar cambio climático y gestión del riesgo de desastres en procesos de OT. Lima: GIZ, 2013.

ARUN, J. N.; RATTAN, L.; ASHESH, K. D. Managing woody bamboos for carbon farming and carbon trading. Global Ecology and Conservation, n. 3, p. 654-663, 2015.

BARNET, Y.; JABRANE, F.; NOLTE, L. Estudio de vulnerabilidad de las viviendas de bambú al cambio climático en el Norte del Perú. Quito: INBAR, 2014.

BOWYER, J. et al. Bamboo products and their environmental impacts: revisited. Minneapolis: Dovetail Partners Inc., 2014.

CAMARGO, J., RODRÍGUEZ, J.; ARANGO, A. Crecimiento y fijación de carbono en una plantación de guadua en la zona cafetera de Colombia. Recursos Naturales y Ambiente, n. 61, p. 86-94, 2010.

CENTRO INTERNACIONAL PARA LA INVESTIGACIÓN DEL FENÓMENO DE EL NIÑO (CIIFEN). Estudio de vulnerabilidad y desarrollo del sistema de información on-line sobre vulnerabilidad frente al cambio climático de la provincia de El Oro. Machala: Secretaría de Gestión Ambiental, 2016.

CENTRO INTERNACIONAL PARA LA INVESTIGACIÓN DEL FENÓMENO DE EL NIÑO (CIIFEN). Vulnerabilidad social, económica y ambiental de la provincia del Guayas: fase I: diagnóstico. Guayaquil: Gobierno Autónomo Descentralizado Provincial del Guayas, 2012.

CENTRO INTERNACIONAL PARA LA INVESTIGACIÓN DEL FENÓMENO DE EL NIÑO (CIIFEN). Información climática de amenazas hidrometeorológicas en las provincias costeras del Ecuador. Guayaquil: CIIFEN, 2007.

CORPORACIÓN ANDINA DE FOMENTO (CAF). Índice de vulnerabilidad y adaptación al cambio climático en la región de América Latina y el Caribe. Caracas: CAF, 2014.

CORPORACIÓN DE PROMOCIÓN DE EXPORTACIONES E INVERSIONES DEL ECUADOR (Corpei). Perfil de producto bambú. Quito: CORPEI-CBI, 2005.

CUESTA, F. et al. Escenarios de impacto del cambio climático sobre la biodiversidad en el Ecuador continental y sus implicaciones en el Sistema Nacional de Áreas Protegidas. Quito: Ministerio del Ambiente del Ecuador, 2015.

ECUADOR. Estrategia nacional del bambú 2018-2022: lineamientos para un desarrollo verde e inclusivo. Quito: Ministerio de Agricultura y Ganadería, 2018.

ECUADOR. Ministerio del Ambiente. Estrategia nacional de cambio climático del Ecuador 2012-2025. Quito: MAE, 2012.

FOOD AND AGRICULTURE ORGANIZATION OF THE UNITED NATIONS (FAO). El estado de los bosques del mundo: las vías forestales hacia el desarrollo sostenible. Rome: FAO, 2018a.

FOOD AND AGRICULTURE ORGANIZATION OF THE UNITED NATIONS (FAO). El estado mundial de la agricultura y la alimentación: agricultura, cambio climático y seguridad alimentaria. Rome: FAO, 2016.

FOOD AND AGRICULTURE ORGANIZATION OF THE UNITED NATIONS (FAO). Encuestas de caracterización socioeconómica nacional en el sector forestal: orientaciones y módulos de encuestas para medir las múltiples funciones de los bosques en el bienestar y los medios de vida del hogar. Rome: FAO, $2018 \mathrm{~b}$. 
FOOD AND AGRICULTURE ORGANIZATION OF THE UNITED NATIONS (FAO). Los bosques y el agua: estudio temático elaborado en el ámbito de la evaluación de los recursos forestales mundiales 2005. Rome: FAO, 2009.

FOOD AND AGRICULTURE ORGANIZATION OF THE UNITED NATIONS (FAO). Managing forests for climate change. Rome: FAO, 2010.

HERRERA, E. Importancia del bambú en el medio ambiente. 2010. Available at: <http://concentracionambiental. blogspot.com/2010_08_01_archive.html.2010>. Access on: 05 Oct. 2018 .

INSTITUTO NACIONAL DE ESTADÍSTICA Y CENSOS (INEC). Censo de población y vivienda 2010. 2015. Available at: <http://www.inec.gob.ec $>$. Access on: 05 Oct. 2018.

INTERGOVERNMENTAL PANEL ON CLIMATE CHANGE (IPCC). Cambio climático 2014: impactos, adaptación y vulnerabilidad. Ginebra: Organización Meteorológica Mundial, 2014.

INTERNATIONAL NETWORK FOR BAMBOO AND RATTAN (INBAR). Carpeta técnica para la producción y manejo de la Gradúa: plan de corta del bambusal. Quito: INBAR, 2010.

JIMÉNEZ, S. et al. Impacto del cambio climático en la agricultura de subsistencia en el Ecuador. Madrid: Fundación Carolina, 2012.

LIM, B.; SPANGER-SIEGFRIED, E. (Eds.). Marco de políticas de adaptación al cambio climático: desarrollo de estrategias, políticas y medidas. New York: PNUD, 2006.

LONDOÑO, X. El bambú en Colombia. Biotecnología Vegetal, v. 11, n. 3, p. 143-154, 2011.

LUDEÑA, C. Y.; WILK, D. Ecuador: mitigación y adaptación al cambio climático: marco de la preparación de la estrategia 2012-2017 del BID en Ecuador. Quito: BID, 2013.

MINISTERIO DEL AMBIENTE DEL ECUADOR (MAE). Cambio climático: principios, políticas y gestión: una guía para la acción ciudadana. Quito: MAE, 2015.

MINISTERIO DEL AMBIENTE DEL ECUADOR (MAE). Segunda comunicación nacional sobre cambio climático, convención marco de las Naciones Unidas sobre cambio climático. Quito: MAE, 2011.

MINISTERIO DEL AMBIENTE DEL ECUADOR (MAE). Sistema de clasificación de ecosistemas del Ecuador continental. Quito: MAE, 2013.

MINISTERIO DEL AMBIENTE DEL ECUADOR (MAE). Tercera comunicación nacional del Ecuador sobre cambio climático. Quito: MAE, 2017.

MONTERROSO, A. et al. Indicadores de vulnerabilidad y cambio climático en la agricultura de México. In:
CONGRESO DE LA ASOCIACIÓN ESPAÑOLA DE CLIMATOLOGÍA, 8., 2012, Salamanca. Proceedings... Salamanca: AEC, 2012. p. 881-890.

MORÁN, J. Manual de construcción con bambú. Guayaquil: INBAR/Universidad Católica Santiago de Guayaquil, 2005.

MORÁN, J. Usos tradicionales y actuales del bambú en América Latina, con énfasis en Colombia y Ecuador. Guayaquil: Escuela Politécnica Nacional, 2001.

MUÑOZ-LÓPEZ，J.; CAMARGO-GARCÍA，J.; ROMERO-LADINO, C. Beneficios de los bosques de guadua como una aproximación a la valoración de servicios ecosistémicos desde la "Jerarquización y Calificación". Gestión y Ambiente, v. 20, n. 2, p. 222-231, 2017.

PAGIOLA, S. et al. Paying for the environmental services of silvopastoral practices in Nicaragua. Ecological Economics, n. 64, p. 374-385, 2007.

POZO, M.; GUTIÉRREZ, J.; RODRIGUEZ, C. El uso del método Delphi en la definición de los criterios para una formación de calidad en animación sociocultural y tiempo libre. Revista de Investigación Educativa, v. 25, n. 2, p. 351-366, 2007.

PRIMAVESI, A. Manejo ecológico del suelo: la agricultura en regiones tropicales. 5. ed. Buenos Aires: El Ateneo, 1984.

SHAWKAT, I. S. et al. Carbon storage in a bamboo (Bambusa vulgaris) plantation in the degraded tropical forests: implications for policy development. Land Use Policy, n. 49, p. 142-151, 2015.

TURBAY, S. et al. Adaptación a la variabilidad climática entre los caficultores de las cuencas de los ríos Porce y Chinchiná, Colombia. 2014. Available at: $<$ http://www.scielo.org.mx/scielo.php?script=sci_artt ext\&pid $=$ S018846112014000300008>. Access on: 05 Oct. 2018.

UMAÑA, V. Bambú Guadua: un recurso ecológico. Tecnología en Marcha, v. 22, n. 3, p. 3-9, 2009.

VANACKER, V. et al. Challenges for research on global change in mainland Ecuador. Neotropical Biodiversity, v. 4, n. 6, p. 114-118, 2018.

YIPING, L. et al. Bamboo and climate change mitigation. Beijing: INBAR, 2010.

YIPING, L.; HENLEY, G. Biodiversity in bamboo forests: a policy perspective for long term sustainability. Beijing: INBAR, 2010.

ZEA, P. Percepciones locales versus evidencia cientifica sobre la relación entre el bambú y el agua en el cantón Bucay, provincia del Guayas, Ecuador. 2013. 167 f. Tesis (Maestría en Agroecología y Ambiente) - Universidad de Cuenca, Cuenca, 2013. 